\title{
The role of Fiscal Institutional Context on primary balance. A case study for European country groups with cultural differences
}

\author{
Dimitra Mitsi ${ }^{\# 1}, \mathrm{PhD}$ \\ Postdoctoral Researcher \\ Department of Economics, University of Piraeus, Greece
}

\begin{abstract}
Many countries have introduced fiscal institutions (fiscal rules and fiscal councils) to deter fiscal indiscipline, reduce macroeconomic forecasting bias and enhance the credibility of fiscal policy. In this study, we use a theoretical model in order to examine how the existence of a fiscal council can reduce a country's debt. In addition, we examine the impact of fiscal institutions on primary balance in 2 European country groups (PIIGCS and DFGNS countries) that have cultural differences. The analysis builds on panel data estimation methods of fixed effects and random effects depending on the Hausman test results. This study finds that the fiscal institutional context (frifc) has a positive and significant effect on PB. More specifically, we find that one change in fiscal institutional context improves PB by a factor of 0.925 and 1.181 in PIIGCS countries and DFGNS countries, respectively.
\end{abstract}

Keywords: Debt, Deficit, Fiscal Institutions, Cultural Differences

\section{INTRODUCTION}

In recent decades, studies focused on institutional determinants which can influence fiscal policy. The impact of fiscal institutions (fiscal rules and fiscal councils) on fiscal measures has been examined by many researchers ([2],[3],[7],[10],[13],[19]). The main idea is that countries with strong fiscal institutions can create fiscal surpluses while weak fiscal institutions can create fiscal deficits.

Fiscal rules play a significant role in the fiscal policy. Kopits and Symansky (1998) [16] defined rules as permanent constraint on fiscal policy. There are 4 categories of fiscal rules. These are budget balanced rules, debt rules, expenditure rules and revenue rules. Fiscal rules are not considered as guidelines because they do not impose constraints on governments. More precisely, fiscal rules support financial policies, foster macroeconomic stability, maintain fiscal policies sustainable, etc. As a result, policy makers will not have the incentive to divert from optimal policies.

Except form fiscal rules, fiscal councils also play a significant role in the conducting of fiscal policy. In particular, fiscal councils can influence the public debate via many ways such as empirical analyses independent from political interference, forecasts and policy recommendations. As a result, there is no lack of transparency and partisan decision makers cannot divert from optimal policies for the social planner. Nevertheless, fiscal rules and fiscal councils do not work separately but they can complement each other to make stronger the enforcement of fiscal rules ([12]).

This paper adds to the literature by examining the role of PIIGCS countries (Portugal, Ireland, Italy, Greece, Cyprus and Spain) and DFGNS countries (Denmark, Germany, The Netherlands, Finland and Sweden) in fiscal policy institutions and how they affect the fiscal performance. First of all, we use different measures of institutions as independent variables. Secondly, we separated some European countries -our sample- between Protestants and Catholics Orthodox. In Protestants countries are included Denmark, Germany, The Netherlands, Finland and Sweden while in Catholic and Orthodox countries are included Portugal, Ireland, Italy, Greece, Cyprus and Spain. Thirdly, we use a theoretical model of fiscal policy inspired by Debrun and Kumar (2013) [12] to explain why fiscal councils are so significant factors as fiscal rules on fiscal policy and finally, we use a dynamic panel method of fixed effects and random effects to estimate our model. 
The rest of the paper is structured as follows: Section two describes the literature review of fiscal institutions while section three explains the theoretical model of the role of fiscal councils on fiscal policy. Methodology is analysed in section four and the empirical results are presented in section five. Finally, in section six are presented some useful remarks on fiscal policy.

\section{LITERATURE REVIEW}

The economic effects of fiscal policy rules are multiple. A growing strand of literature finds a positive effect of FR on fiscal outcomes ([1],[2],[7],[10],[13],[14],[19]). For instance, Debrun et al. (2008) [10] by using data from 25 countries of the European Union show that the stronger a country's fiscal rules, the higher the cyclically adjusted primary balance. However, rules like deficit and debt are more effective with regard to that expenditure rules.

In addition, Ayuso-i-Casalo et al (2007) [2] in a similar dataset and having deficits and long-term debt as dependent variable find that an increase in the share of government finances covered by fiscal rules lead to lower deficit. In the same way, Alesina and Bayoumi (1996) [1] by using ratio of primary and total surplus to state product as a dependent variable in a sample of $50 \mathrm{US}$ states find that in American states budget balanced rules are effective in enforcing fiscal discipline and stricter fiscal rules are associated with the creation of larger surpluses and more stable lower cyclical budget balance.

Moreover, Clingermayer and Wood (1995) [7] by using different kind of fiscal rules -expenditure rules and debt rules- as independent variables and government indebtness as dependent variables find that debt rules have no correlations on government indebtness when budget balanced rules are controlled.

Furthermore, IMF (2013) [15] by using an econometric model for 26 countries and ([8],[9]) by using a multivariate panel data for European countries find that Fiscal Rule Index and Fiscal Council have significant impact on fiscal performance and at the same time Fiscal council is a complementary to the Fiscal Rule Index. Besides, the positive impact of fiscal rules on fiscal outcomes is very important but at the same time we need to be more cautious as it could be reflecting the impact of omitted variables like the political commitment [20]. In addition, stringent fiscal rules may be counterproductive for countries which are pursuing the application of structural reforms.

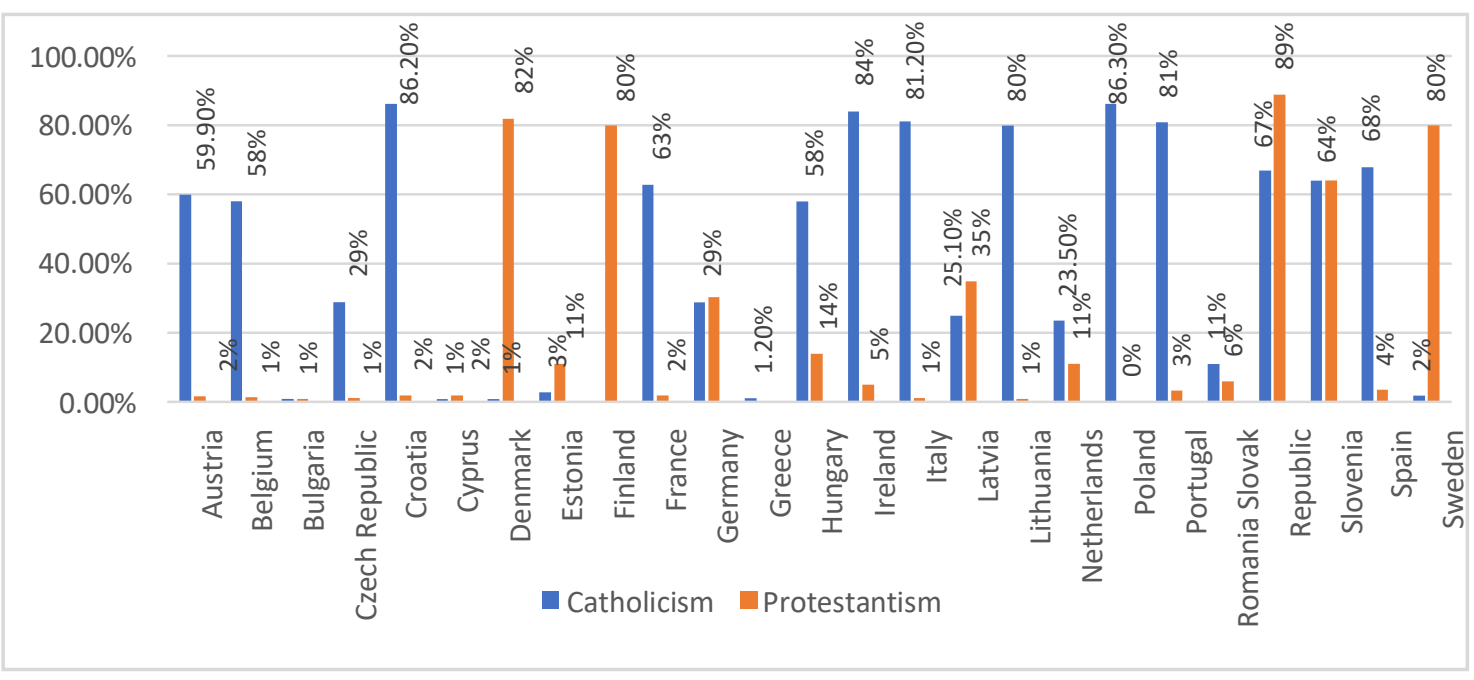

Figure 1: Percentage of Catholicism-Orthodox and Protestantism in European Countries (EU-28)

A vast literature examines the differences between cultural country groups (e.g., Protestants and Catholics (Figure 1)) and how these different cultural country groups obey or not to fiscal policy rules ([4],[17],[21]). For instance, Chadi and Krapf (2015) [6] report that Catholics were not doing better economically than Protestants and Protestantism's also care more about rules. In addition, Becker and Woessmann (2009) [4] provide evidence that in $19^{\text {th }}$ century Protestants had higher literacy rates than Catholics while [17] find that trust is higher in Protestant countries than in Catholics countries. 
However, a new approach for fiscal institutions is to examine how different country groups (with cultural differences) like PIIGCS which had many economic problems during the crisis and DFGNS countries which characterized by low debt $\%$ of gdp and high surpluses (see Figure $2 \& 3$ ) react to fiscal institutions.

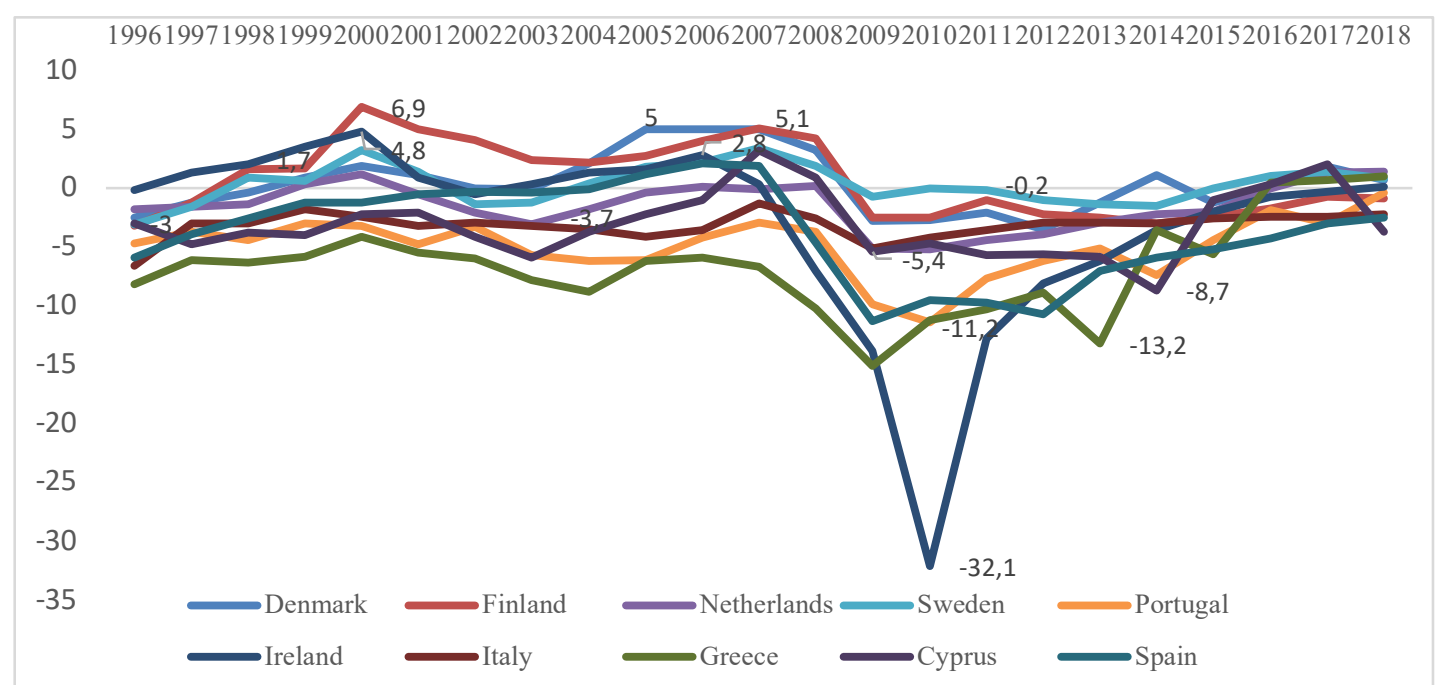

Figure 2: Primary Balance as a percentage of GDP in PIIGCS and DFGNS countries from 1996 to 2018

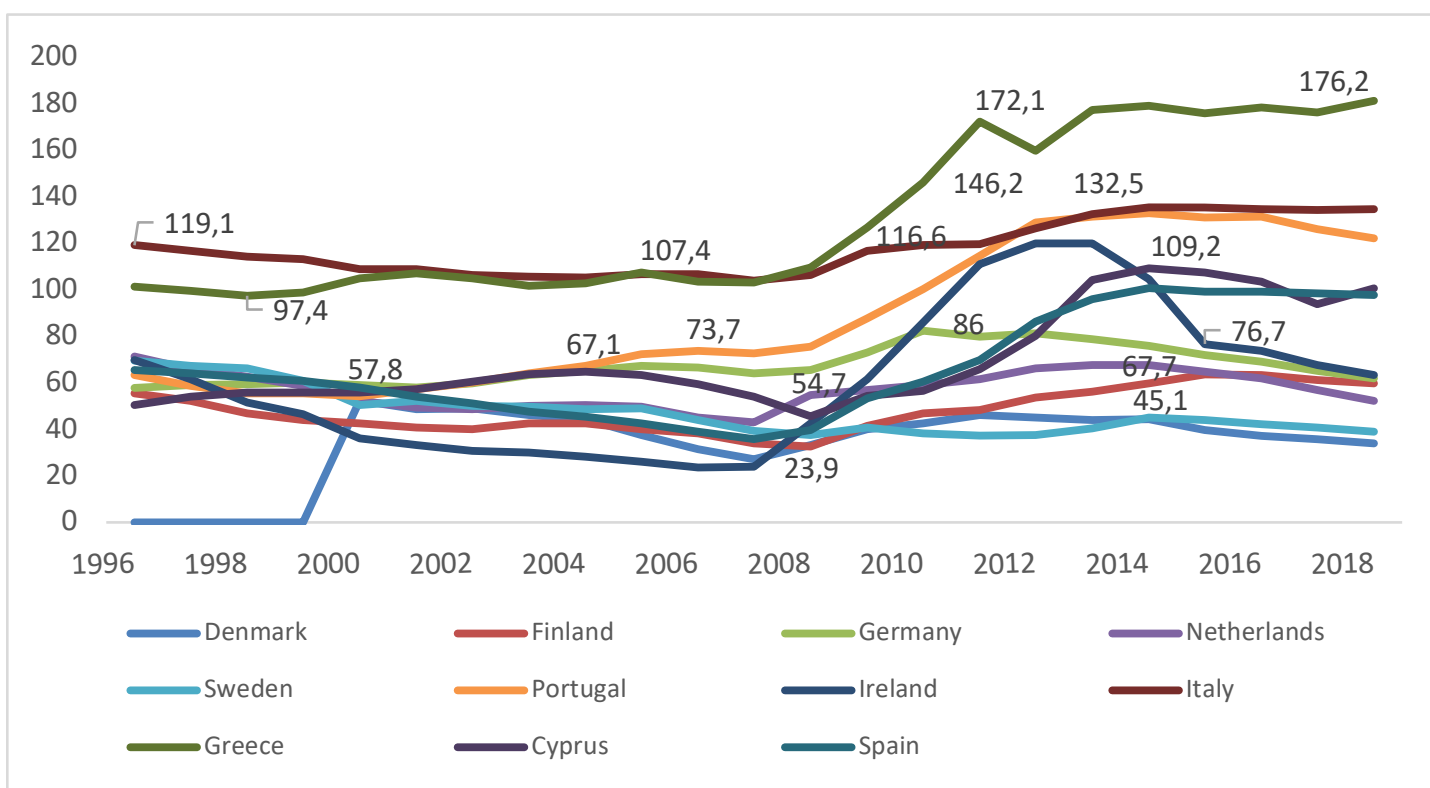

Figure 3: Debt as a percentage of GDP in PIIGCS and DFGNS countries from 1996 to 2018

\section{Theoretical Model}

Let's begin our analysis (inspired by [12]) by assuming that we have a small economy, two time periods and one utility function which derives from the consumption of private goods and spending on public goods. As a result, the individual's preferences are represented by equation A.

$$
P=\mathrm{E}_{0}\left[\sum_{\mathrm{t}=1}^{2} \mathrm{x}\left(g \mathrm{pr}_{\mathrm{t}}\right)+\mathrm{z}\left(g \mathrm{p}_{\mathrm{ppt}}\right)\right]
$$

According to the equation (A), gpr $r_{t}$ represents the consumption of private goods in time periods 1 and 2 and, while $g p_{t}$ represents the spending on public goods in time periods 1 and 2 . In addition, the sub-utility functions 
$\mathrm{x}\left(g \mathrm{pr}_{\mathrm{t}}\right)$ and $\mathrm{z}\left(g \mathrm{p}_{\mathrm{ppt}}\right)$ are twice continuously differentiable and the consumer's intertemporal constrain can be written as in equation $(\mathrm{B})$ and $(\mathrm{C})$.

$$
\begin{aligned}
& g \mathrm{pr}_{1}=(1-\operatorname{taxr}) \mathrm{en}_{1}+\mathrm{po} \\
& g p r_{2}=(1-\text { taxr }) e n_{2}-\mathrm{po}
\end{aligned}
$$

where taxr expresses the income tax rate, $e n_{t}$ expresses an endowment economy at time $t$ and po represents the net private liabilities at the end of period 1 . Taking into account that the consumption of private goods in period 1 and in period 2 is greater or equal to zero, then equation (B) can be expressed as follows:

$$
\begin{gathered}
g \mathrm{pr}_{1} \geq 0 \\
(1-\mathrm{taxr}) e n_{1}+p o \geq 0 \\
\text { po } \geq-(1-t r) e_{1} \\
g \mathrm{pr}_{2} \geq 0 \\
(1-\operatorname{taxr}) e n_{2}+p o \geq 0 \\
\text { po } \geq-(1-t r) e_{2}
\end{gathered}
$$

As a result, by combining equation $(\mathrm{E})$ and $(\mathrm{G})$ we have:

$$
(1-\operatorname{taxr}) * e n_{1} \leq \mathrm{pl} \leq(1-\operatorname{tax} r) * e n_{2}
$$

Furthermore, let's assume that we have 2 political parties. One political party is a conservative party (conp) and the other political party is a liberal party (lbrp). However, the ideology for each political party does not have a significant role. In our model we have also another mechanism where policymakers cannot increase the debt over a certain threshold. As a result, the utility cost for policy decision-makers is

$$
\begin{aligned}
& \text { ut } \left.(\mathrm{d})=0 \text { if } \mathrm{d} \leq d_{\text {thres }}\right) \quad \text { and } \\
& \text { ut }(\mathrm{d})=(\mathrm{fr}+\mathrm{fs})\left(\mathrm{d}-d_{\text {thres }}\right)
\end{aligned}
$$

where $\mathrm{d}-d_{\text {thres }}$ is the numerical fiscal rule, fr is the mechanism which oblige policy decision-makers to comply with fiscal rules and fs is an effective fiscal council which inform us about the compliance with the fiscal rules or not. Policy-makers utility function can be expressed as follows:

$$
\mathrm{T}=E_{0}\left[\sum_{t=1}^{2} x\left(g p r_{t}\right)+z\left(g p_{p p t}\right)-u t(d)\right], \mathrm{PP}=\text { conp, lbrp }
$$

According to (I), the intertemporal budget constrain can be written as in equations (JA) and (JB):

$$
\begin{aligned}
& g p_{P P, 1}=\text { taxren }_{1}+d-h \\
& g p_{P P, 2}=\text { taxren }_{2}-d-h
\end{aligned}
$$

where $h$ represents the ability of policy decision- makers to deliver public goods. Moreover, as we mentioned previously, the ideology of political parties does not play an important role in our model and then $h_{1}=h_{2}=\frac{h}{2}$. Finally, the income in period 1 is equal to $\overline{\mathrm{en}}(1+\mathrm{rd})$ and $\mathrm{rs}$ is a random shock. In period 2 , the income is equal to $\overline{\mathrm{en}}$.

\section{The Optimal Fiscal Equilibrium}

The optimal level of fiscal equilibrium is the level of debt which maximizes the expected utility of voters. Taking into account the social equilibrium we can write.

$$
\begin{gathered}
\mathrm{d}^{*}=\max _{d}(X)=\max _{d}\left[x\left(g p r_{1}\right)+w\left(g p r_{2}\right)+y\left(g p_{p p 1}\right)+y\left(g p_{p p 2}\right)\right] \\
\mathrm{d}^{*}=\max _{d}(X)=\max _{d}\left[x\left(g p r_{1}\right)+x\left(g p r_{2}\right)+y\left(\operatorname{taxr} \overline{e n}+d^{*}-\frac{h}{2}\right)+y\left(\operatorname{taxr} \overline{e n}-d^{*}-\frac{h}{2}\right)\right]
\end{gathered}
$$

The first order of equation $(\mathrm{K})$ can be written as follows:

$$
\begin{gathered}
\mathrm{d}^{*}=\max _{d}(X)=\max _{d}\left[2 x\left(p r_{1}\right)+y\left(\operatorname{taxr} \overline{\operatorname{en}}+d^{*}-\frac{h}{2}\right)+y\left(\operatorname{taxr} \bar{e} n-d^{*}-\frac{h}{2}\right)\right] \\
0+z^{\prime}\left(\operatorname{taxr} \overline{e n}(1+r s)+d^{*}-\frac{h}{2}\right)+z^{\prime}\left(\operatorname{taxr} \overline{e n}-d^{*}-\frac{h}{2}\right)=0 \\
z^{\prime}\left(\operatorname{taxr} \overline{e n}(1+r s)+d^{*}-\frac{h}{2}\right)=-z^{\prime}\left(\operatorname{taxr} \overline{e n}-d^{*}-\frac{h}{2}\right)
\end{gathered}
$$




$$
\begin{gathered}
\operatorname{taxr} \overline{\overline{e n}}(1+r s)+d^{*}-\frac{h}{2}=\operatorname{taxr} \overline{\operatorname{en}}-d^{*}-\frac{h}{2} \\
\operatorname{taxr} \overline{\overline{e n}}+\operatorname{taxr} \overline{\operatorname{enr} s}+d^{*}-\frac{h}{2}=\operatorname{taxr} \overline{\overline{e n}}-d^{*}-\frac{h}{2} \\
2 d^{*}=\operatorname{taxr} \overline{\overline{e n r}} s-\frac{h}{2}+\frac{h}{2} \\
\mathrm{~d}^{*}=\frac{\text { taxrēnrs }}{2}
\end{gathered}
$$

\section{Equilibrium of Policy Makers and the Impact of Fiscal Councils}

According to policy-makers equilibrium the debt can be written as follows:

$$
\begin{array}{r}
\mathrm{d}^{* *}=\max _{d}(T)=\max _{d}\left[x\left(g p r_{1}\right)+x\left(g p r_{2}\right)+z\left(g p_{p p 1}\right)+y\left(g p_{p p 2}\right)-u t(d)\right] \\
\max _{d}(P)=\max _{d}\left[x\left(g p r_{1}\right)+x\left(g p r_{2}\right)+y\left(\operatorname{taxr} \overline{e n}+d^{* *}-\frac{h}{2}\right)+y\left(\operatorname{taxr} \overline{e n}-d^{* *}-\frac{h}{2}\right)-\right.
\end{array}
$$

It is noted that a policymaker has a greater discount rate equal to (1-dr) than social planner as a consequence of the uncertainty about the re-election. As a result, the first order of equation (M) defined as:

$$
\begin{aligned}
& z^{\prime}\left(\operatorname{taxr} \bar{e} n(1+r s)+d^{*}-\frac{h}{2}\right)+(1-d r) z^{\prime}\left(\operatorname{taxr} \overline{e n}-d^{*}-\frac{h}{2}\right)-u c\left(d^{* *}\right)=0 \\
& z^{\prime}\left(\operatorname{trax} \overline{e n}(1+r s)+d^{*}-\frac{h}{2}\right)=(1-d r) z^{\prime}\left(\operatorname{taxr} \overline{\bar{n}}-d^{*}-\frac{h}{2}\right)+u c\left(d^{* *}\right) \\
& \begin{array}{ll}
\text { If } \quad \mathrm{d}^{* *} \leq \mathrm{d} \text { thres } & \text { then } \quad\left(u c\left(d^{* *}\right)=0\right)
\end{array}
\end{aligned}
$$

or

$$
\text { If } \mathrm{d}^{* *} \geq \mathrm{d} \text { thres then } \quad\left(u c\left(d^{* *}\right)=f r+f s\right),
$$

where $f r+f s=\operatorname{dr} y z^{\prime}\left(g p_{p p 1}\right)$ assuming $r s=0$.

To sum up, the debt level of the political equilibrium is greater than the debt level in the social equilibrium. However, the enforcement of a fiscal rule and the existence of a fiscal council equalize the debt level of political equilibrium with the debt of social equilibrium.

The same explanation for the equilibrium between social and political equilibrium can be expressed with the Figure 4. According to Figure, the point $\mathrm{A}$ is the intersection between 2 curves. The first curve $\mathrm{z}^{\prime}\left(g p_{p p 1}\right)$ expresses the marginal utility for public good 1 and the second curve $z^{\prime}\left(g p_{p p 2}\right)$ expresses the marginal utility for public good 2. In other words, point A identifies the social equilibrium (optimal equilibrium).

However, the uncertainty about re-election increases the discount rate of the expected margin utility leading to a new balance at point $\mathrm{B}$. In point $\mathrm{B}$ there is an intersection between the curve $z^{\prime}\left(g p_{p p 1}\right)$ and (1dr) $z^{\prime}\left(g p_{p p 2}\right)$ where the debt level $\left(\mathrm{d}^{* *}\right)$ is greater than in point A ( $\mathrm{d}^{*}$-optimal debt level).

At this point, if the government enforce a fiscal rule equal to fr then, the curve (1dr) $\mathrm{yz}^{\prime}\left(\mathrm{gp}_{\mathrm{pp} 2}\right)$ goes down at point $\mathrm{C}$ reducing the debt level from $\mathrm{d}^{* *}$ level to $\mathrm{d}^{* * *}$ level. Finally, the existence of an effective fiscal council pushes down even more the utility curve (1-dr) $z^{\prime}\left(g p_{p p 2}\right)$ bringing the debt level $\mathrm{d}^{* * *}$ to the initial debt (optimal debt) at point A. In other words, a combination between an effective fiscal council and a strong enforcement of fiscal rule equalizes the social and political equilibrium at level $\mathrm{d}^{*}([5],[11],[12])$. 


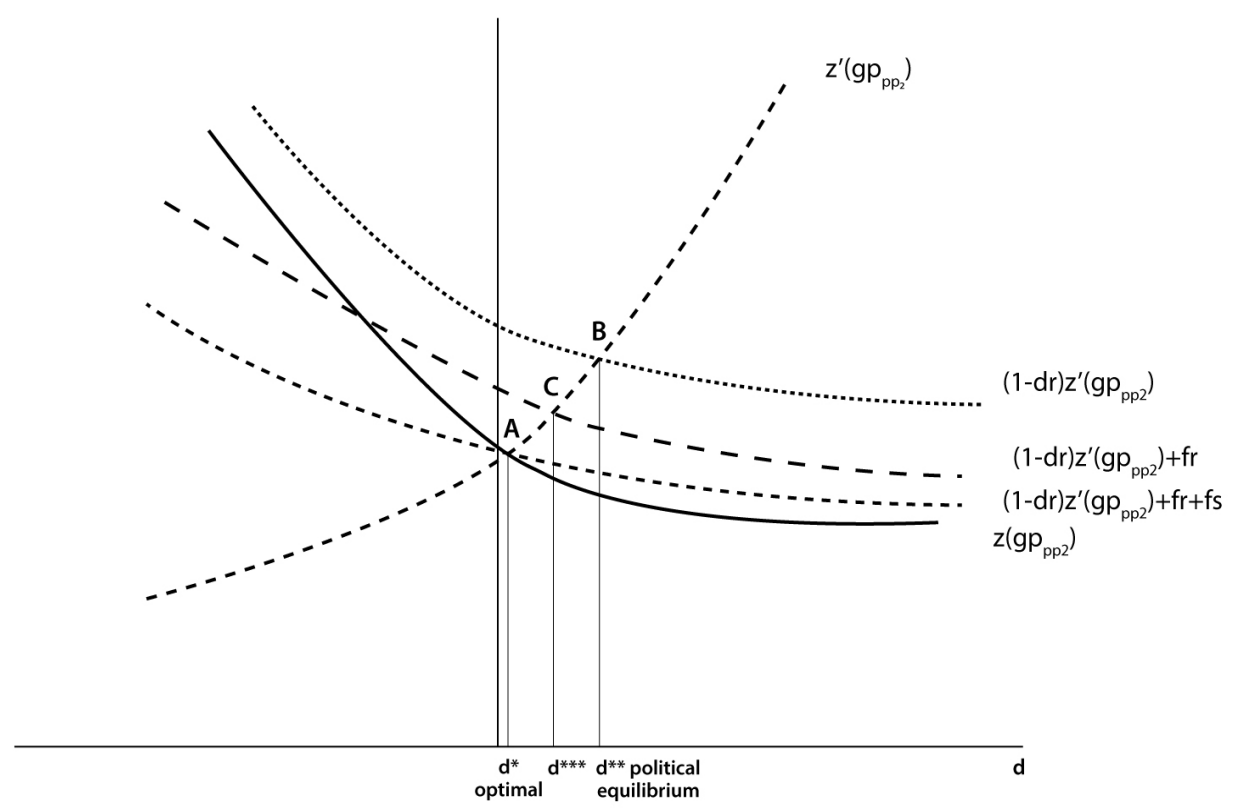

Figure 4: A graphical illustration of social and political equilibrium

\section{Methods}

In our study, we examine the role of fiscal institutions in PIIGCS countries and DFGNS countries. In the first country group are included Portugal, Ireland, Italy, Cyprus, Greece and Spain-PIIGCS countries and in the second country group are included Denmark, Finland, Germany, the Netherlands and Sweden-DFGNS countries. Our data are annual and covers the period from 1996 to 2018. Based on the above analysis, we use a standard set up which describes a reaction function as proposed by Bohn (1998) [12].

$$
\mathrm{pb}=\alpha+\beta 1 \mathrm{fr}+\beta 2 \mathrm{fc}+\gamma \mathrm{cvit}+\text { nit }+ \text { eit }, \quad \mathrm{t}=1,2 \ldots \ldots \ldots \mathrm{t}, \mathrm{i}=1,2, \ldots \mathrm{n}
$$

In our baseline scenario, firstly, we test for the basic factors of primary balance such as debt (measured by debt as a percentage of gdp-debt), real growth rate (measured by annual percentage growth of gdp-gro), trade openness (measured by sum of exports and imports as a percentage of gdp-to), unemployment rate (measured by the percentage of labor force that is without job-un) and inflation (measured by the annual percentage change of cpi-inf). Then, we add the fiscal institutions variables including fiscal rule index-fri, and fiscal council (measured by a dummy variable- to measure the existence of fiscal council-fc).

Data are derived from several sources. More precisely, debt, primary balance and unemployment are derived from Eurostat while growth rate and trade openness are derived from World Bank's Worldwide Development Indicators. Inflation is derived from United Nations Conference on Trade and Development (UNCTAD) and Fiscal Rule Index is derived from European Commission. Finally, dummy for fiscal councils derived from the database of International Monetary Fund.

The empirical framework is based on a panel data analysis by employing 2 econometric approaches. We use fixed effects and random effects estimations depending on Hausman test results.

\section{EMpirical ANALYsis}

Table 1 and Table 2 presents the descriptive statistics of DFGNS and PIIGCS countries. As we can see from a simple observation, DFGNS countries display on average lower debt, primary balance, and unemployment rates than PIIGCS countries and they have higher rates of growth.

Table 3 reports the random effects panel estimation for PIIGCS countries (Hausman Test, Prob=0,3742>0,05. We cannot reject the null hypothesis. So, the appropriate estimation model is the random effects). The first column presents the basic model and the other columns present different model specifications. According to the empirical results in Table 3, there is a positive and statistically significant relationship between $\mathrm{pb}$ and one lagged pb (0.596), 
debt (0.046), real growth (0.373), inf (0.565) fri (1.148) and frifc (0.921). For example, one change in fiscal institutional context (frifc) improves PB by a factor of 0.925 in PIIGCS countries. These empirical results completely confirm with the relevant literature ([12],[18]). It is noted that tables 3 and 4 present the coefficients and their standard deviation (in parenthesis) of PIIGCS countries and DFGNS countries for the period from 1996 to 2018. So, * denotes significance level of $10 \%, * *$ denotes significance level of $5 \%$ and $* * *$ denotes significance level of $1 \%$.

Table 1 Descriptive Statistics for DFGNS

\begin{tabular}{|c|c|c|c|c|}
\hline Variables & Mean & Std. Deviation & Min & Max \\
\hline pb & -1.685 & 3.186668 & -11.4 & 5.1 \\
\hline debt & 67.105 & 28.238 & 27.3 & 132.9 \\
\hline gro & 0.9758117 & 2.480583 & -8.074616 & 5.299005 \\
\hline to & 96.05567 & 26.62537 & 61.49 & 157.82 \\
\hline un & 7.280167 & 2.786887 & 3.38 & 16.18 \\
\hline inf & 1.463167 & 1.052235 & -0.84 & 4.07 \\
\hline fri & 1.050333 & 1.018269 & $-0 . .3$ & 3,5 \\
\hline fc & 0.7666667 & 0.4265219 & 0 & 60 \\
\hline Observations & 60 & 60 & 60 & \\
\hline & & & & \\
\hline
\end{tabular}

Table 2 Descriptive Statistics for PIIGCS

\begin{tabular}{|c|c|c|c|c|}
\hline Variables & Mean & Std. Deviation & Min & Max \\
\hline pb & $-5,194444$ & 5.234606 & -32.1 & 3.2 \\
\hline debt & 105,5778 & 37.79642 & 23.9 & 181.2 \\
\hline gro & 0,807332 & 4.589074 & -9.132494 & 25.16253 \\
\hline to & 94,74722 & 51.45117 & 45.42 & 226.04 \\
\hline un & 13,16194 & 6.097199 & 3.65 & 27.47 \\
\hline inf & 1,205 & 1.800451 & -4.48 & 2.8 \\
\hline fri & 0.6373611 & 1.199555 & -0.97 & 1 \\
\hline fc & 0.5416667 & 0.5017575 & 0 & 72 \\
\hline Observations & 72 & 72 & 72 & 4.9 \\
\hline
\end{tabular}


Table 3 Random effects panel data estimations for PIIGCS countries from 1996 to 2018 (yearly data)

\begin{tabular}{|c|c|c|c|c|c|}
\hline Variables & Basic Model & Model 2 & Model 3 & Model 4 & Model 5 \\
\hline \multirow[t]{2}{*}{ L.pb } & $0.596 * * *$ & $0.532 * * *$ & $0.553 * * *$ & $0.551 * * *$ & $0.551 * * *$ \\
\hline & $(0.029)$ & $(0.052)$ & $(0.059)$ & $(0.039)$ & $(0.039)$ \\
\hline \multirow[t]{2}{*}{ debt } & $0.046 * * *$ & $0.044 * * *$ & 0.012 & $0.041 * * *$ & $0.041 * * *$ \\
\hline & $(0.013)$ & $(0.011)$ & $(0.025)$ & $(0.010)$ & $(0.010)$ \\
\hline \multirow[t]{2}{*}{ gro } & $0.373 * * *$ & $0.241 * *$ & 0.249 & $0.283^{* * *}$ & $0.283 * * *$ \\
\hline & $(0.082)$ & $(0.102)$ & $(0.155)$ & $(0.077)$ & $(0.077)$ \\
\hline \multirow[t]{2}{*}{ to } & 0.003 & $0.011 * *$ & -0.010 & $0.009 *$ & $0.009^{*}$ \\
\hline & $(0.003)$ & $(0.004)$ & $(0.013)$ & $(0.004)$ & $(0.004)$ \\
\hline \multirow[t]{2}{*}{ un } & 0.028 & -0.024 & -0.033 & 0.045 & 0.045 \\
\hline & $(0.048)$ & $(0.077)$ & $(0.092)$ & $(0.060)$ & $(0.060)$ \\
\hline \multirow[t]{2}{*}{$\inf$} & $0.565^{*}$ & $0.746^{* *}$ & $0.584^{*}$ & $0.755^{*}$ & $0.755^{*}$ \\
\hline & $(0.337)$ & $(0.358)$ & $(0.302)$ & $(0.386)$ & $(0.386)$ \\
\hline \multirow[t]{2}{*}{ fri } & & $1.148^{*}$ & & & \\
\hline & & $(0.696)$ & & & \\
\hline \multirow[t]{2}{*}{ fc } & & & 3.705 & & \\
\hline & & & $(3.331)$ & & \\
\hline \multirow[t]{2}{*}{ frifc } & & & & $0.921 *$ & \\
\hline & & & & $(0.539)$ & \\
\hline \multirow[t]{2}{*}{ Constant } & $-8.794 * * *$ & $-9.987 * * *$ & $-5.405 * *$ & $-10.138 * * *$ & $-10.138 * * *$ \\
\hline & $(1.815)$ & (2.624) & $(2.543)$ & (2.493) & (2.493) \\
\hline Observations & 66 & 66 & 66 & 66 & 66 \\
\hline $\begin{array}{l}\text { Number of } \\
\text { countries }\end{array}$ & 6 & 6 & 6 & 6 & 6 \\
\hline
\end{tabular}

On the other hand, Table 4 reports the fixed effects panel estimations for DFGNS countries (Hausman Test, Prob $=0,00<0,05$. We can reject the null hypothesis. So, the appropriate estimation model is the fixed effects). The same results are reported for DFGNS countries in Table 4. More specifically, there is a positive and statistically significant relationship between $\mathrm{pb}$ and one lagged $\mathrm{pb}(0.592)$, debt $(0.037)$, real growth $(0.276)$, to $(0.107)$ fri (1.245) and frifc $(1,181)$. For example, one change in fiscal institutional context (frifc) improves PB by a factor of 1.181 in DFGNS countries. 
Table 4 Fixed effects panel data estimations for DFGNS countries from 1996 to 2018 (yearly data)

\begin{tabular}{|c|c|c|c|c|c|}
\hline Variables & Basic Model & Model 2 & Model 3 & Model 4 & Model 5 \\
\hline \multirow[t]{2}{*}{ L.pb } & $0.592 * * *$ & $0.519 * * *$ & $0.580 * *$ & $0.543 * * *$ & $0.543 * * *$ \\
\hline & $(0.127)$ & $(0.091)$ & $(0.131)$ & $(0.094)$ & $(0.111)$ \\
\hline \multirow[t]{2}{*}{ debt } & $0.037 *$ & 0.008 & 0.015 & 0.014 & 0.028 \\
\hline & $(0.017)$ & $(0.016)$ & $(0.010)$ & $(0.016)$ & $(0.017)$ \\
\hline \multirow[t]{2}{*}{ gro } & 0.276 & 0.194 & 0.259 & 0.197 & 0.210 \\
\hline & $(0.152)$ & $(0.124)$ & $(0.157)$ & $(0.134)$ & $(0.147)$ \\
\hline \multirow[t]{2}{*}{ to } & $0.107 *$ & 0.025 & $0.108 *$ & 0.029 & 0.062 \\
\hline & $(0.045)$ & $(0.017)$ & $(0.044)$ & (0.019) & $(0.037)$ \\
\hline \multirow[t]{2}{*}{ un } & -0.139 & -0.033 & -0.082 & -0.026 & -0.163 \\
\hline & $(0.107)$ & $(0.110)$ & $(0.125)$ & $(0.116)$ & $(0.157)$ \\
\hline \multirow[t]{2}{*}{ inf } & 0.350 & $0.960 * *$ & 0.391 & $0.944 * *$ & $0.694 *$ \\
\hline & $(0.273)$ & $(0.302)$ & $(0.302)$ & $(0.301)$ & $(0.318)$ \\
\hline \multirow[t]{2}{*}{ fri } & & $1.245 * *$ & & & \\
\hline & & $(0.438)$ & & & \\
\hline \multirow[t]{2}{*}{ fc } & & & 0.753 & & \\
\hline & & & $(0.661)$ & & \\
\hline \multirow[t]{2}{*}{ frifc } & & & & $1.181 * *$ & \\
\hline & & & & $(0.425)$ & \\
\hline \multirow[t]{2}{*}{ Constant } & $-13.472 * *$ & $-6.635 * * *$ & $-13.069 * *$ & $-7.384 * * *$ & $-9.421 * *$ \\
\hline & $(4.030)$ & (1.012) & (3.837) & (1.289) & $(2.722)$ \\
\hline Observations & 55 & 55 & 55 & 55 & 55 \\
\hline R-squared & 0.741 & 0.795 & 0.745 & 0.790 & 0.765 \\
\hline Number of countries & 5 & 5 & 5 & 5 & 5 \\
\hline
\end{tabular}

\section{CONCLUSIONS}

Many researchers have examined the role of fiscal institutions on primary balance and how countries can improve their fiscal positions. In this study, we focused on assessing and comparing theoretically and empirically the impact of different fiscal frameworks including fiscal rules and fiscal councils on primary balance as well as how the results are differentiated for different sample of countries (PIIGCS and DFGNS) which have culture differences. We apply panel regressions for 2 country groups from 1996 to 2018 where the primary budget balance is the dependent variable.

The results confirm that the fiscal institutional context quality variables of fiscal rule index and fiscal council have a positive and significant effect on primary balance in PIIGCS countries as well as in DFGNS countries. In addition, the empirical results show that one lagged primary balance, real growth, inflation and trade openness are important determinants for these 2 groups.

Finally, the outcome of the empirical analysis has policy implications giving us the factors that are so important for creating fiscal surpluses. Future researches should focus on different institutions and their effect on primary balance as well as how such institutions impact on different dependent variables. 


\section{REFERENCES}

[1] Alesina, A., Bayoumi, T. 1996. The costs and benefits of fiscal rules: Evidence from U.S. states. NBER Working Paper 5614.NationalBureauofEconomicResearch, Cambridge.

[2] Ayuso-i-Casals, J., Gonzáles Hernandez, D., Moulin, L., Turrini, A.2007. Beyond the SGP: Features and effects of EU national- level fiscal rules. Policy instruments for Sound Fiscal Policies, pp 204-240.

[3] Badinger, H., Reuter, W.H. 2017. The case of fiscal rules. Economic Modelling, vol 60, pp 334-343.

[4] Becker, S. O., and Woessmann, L.2009. "Was Weber Wrong? A human Capital Theory of Protestant Economic theory," Quarterly Journal of Economics, 124 (2),531-596.

[5] Calmfors, L., \& Wren-Lewis, S. (2011), "What Should Fiscal Councils do? Economic Policy”, 26(68), 649-695.

[6] Chadi, A. and Krapf, K. 2015. "The Protestant Fiscal Ethic: Religious Confession and Euro Skepticism in Germany, German SocioEconomic Panel Study(SOEP), Berlin, April.

[7] Clingermayer, J.C.,Wood, B.D. 1995. Disentangling patterns of state debt financing. American Political Science Review 89 (1), 108 120.

[8] Debrun, X., Kumar, M.S.2007a. Fiscal rules, fiscal councils and all that: Commitment devices, signaling tools or Fiscal policy smoke screens? in: Bancad' Italia (Ed.): Current issues and challenges. Papers presented at the Banca d' Italia workshop held in Perugia, 2931 March 2007, Roma, pp.479-512.

[9] Debrun, X., Kumar, M.S. 2007b. The discipline-enhancing role of fiscal institutions: Theory and empirical evidence. International Monetary Fund, Washington. IMF Working Paper WP/07/171.

[10] Debrun, X., Moulin, L., Turrini, A., Ayuso-i-Casalas, J., Kumar, M.S. 2008. Tied to the mast? National fiscal rules in theEuropean Union. Economic Policy 23 (54), 297-362.

[11] Debrun, X., T. Kinda, T. Curristine, L. Eyraud, J. Harris, and J. Seiwald (2013), “The Functions and Impact of Fiscal Councils," IMF Policy Paper, available at http://www.imf.org/external/np/fad/council/.

[12] Debrun et al. (2013). The Functions and Impact of Fiscal Councils. IMF Working paper. International Monetary Fund.

[13] Feld, L.P., Kirchgässner, G. 2006. “On the effectiveness of debt brakes: The Swiss experience”, CREMA Working Paper 21. Center for Research in Economics, Management and the Arts, Basel.

[14] Hallerberg, M., R. Strauch and von Hagen, J. 2001. "The Use and Effectiveness of Budgetary Rules and Norms in EU Member States", Report of the Institute of European Integration Studies for the Dutch Ministry of Finance, June

[15] International Monetary Fund. 2012. Fiscal performance, institutional design and decentralisation in European Union countries. International Monetary Fund, WP/12/45, 2012.

[16] Kopits, G., Symansky S. 1998. Fiscal Policy Rules, Occasional Paper, No. 162, International Monetary Fund. Washington, DC.

[17] La Porta, R., Lopez-de Silanes, F. and Vishny, R.W.1997. “Trust in Large Organizations," American Economic Review $\mathrm{P} \& \mathrm{P}, 87(2), 333-38$.

[18] Mitsi, D. (2021). "Does the quality of Fiscal Institutions matter for fiscal Performance. A panel data analysis of European Countries". International Journal of Economics and Finance. 13(1), 33-44.

[19] Nice, D.C.1991. The impact of state policies to limit debt financing. Publius 21 (1), 69-82.

[20] Schaechter, A., Kinda, T., Budina, N., and Weber, A. 2012) "Fiscal Rules in Response to the Crisis - Toward the 'Next-Generation' Rules". A New Dataset. IMF Working Paper, 12(187).

[21] Stulz, R.M., and Williamson, R. 2003. "Culture, openness and finance”. Journal of Financial Economics, (70(3),313-349. 